\title{
Effect of Planting Time and Genotypes on Seed Yield, Quality Parameters and Economics on Safflower
}

\author{
G. Somanagouda ${ }^{1 *}$, T. T. Bhandiwaddar ${ }^{1}$ and Manjula Maralappanavar ${ }^{2}$ \\ ${ }^{1}$ AICRP on Sorghum, MARS, UAS, Dharawad-58005, India \\ ${ }^{2}$ Genetics \& Plant Breeding, ARS, Hebballi Farm, Dharwad-580 005, India \\ *Corresponding author
}

\section{A B S T R A C T}

A field experiment was conducted of Agricultural Research Station, Annigeri, University of Agricultural Sciences, Dharwad during rabi season

\section{Keywords}

Oil content, Annigeri-1,

Safflower,

Economics

\section{Article Info}

Accepted:

07 March 2020

Available Online:

10 April 2020 of 2015-16, under rainfed conditions. The experiment was laid out in a split-plot design and replicated thrice. Main plots consists of three date of sowing $-\mathrm{D}_{1}$ : 1-10-2015, $\mathrm{D}_{2}$ : 15-10-2015, $\mathrm{D}_{3}: 31-10-2015$ and three sub plots, genotypes, $\mathrm{G}_{1}-\mathrm{A}_{1}, \mathrm{G}_{2}$-NARI-6 and $\mathrm{G}_{3}$-NARI-57. Among the different date of sowing significantly higher seed yield $\left(946 \mathrm{~kg} \mathrm{ha}^{-1}\right)$ was observed in $1^{\text {st }}$ date of sowing as compared to third date of sowing (783 kg $\left.\mathrm{ha}^{-1}\right)$. Among the genotype, Annigeri-1, recorded significantly higher yield $\left(1033 \mathrm{~kg} \mathrm{ha}^{-1}\right)$ as compared to other two genotypes NARI-6 (799 kg ha-1) and NARI-57 (825 $\left.\mathrm{kg} \mathrm{ha}^{-1}\right)$, with respect to oil content and oil yield no significantly difference were observed with different date of sowing. Among the genotypes, NARI-6, recorded significantly higher oil content $(34.41 \%)$ as compared to Annigeri-1 (28.83\%).

\section{Introduction}

Safflower growth and productivity are influenced by many factors such as genotype, environment and agronomic practices. It is mainly grown in semi-arid regions for use as vegetable and industrial oil. Safflower is a crop species which is well adapted to dry and salty land conditional since it is a strongly tap-rooted annual plant which is resistant to saline conditions, drought stress and can reach the deep lying water $(1,13)$. Also low production costs and low water and nutrient need appeal to farmers as an alternative to other crops.

However, safflower yields are generally lower than the yield of other oilseed crops $(4,5,10)$. The importance of safflower as oilseed crop has increased in recent years, especially with 
the increasing interest in the production of biofuels. Safflower, in general, performs better when it succeeds a short duration legumes like mungbean, blackgram and groundnut (during kharif) than cereal crops like sorghum and maize due to favourable moisture regimes and residual fertility.

Hence, it offers an excellent opportunity for doubling the existing level of cropping intensity and there by steps up returns from rainfed, farming in many conventional monos cropped areas. Growing of groundnut during kharif and safflower during rabi season in sequence in areas where the rainfall is fairly well distributed from June to October found advantageous under suitable nutrient management practices. Safflower oil preferred for its higher poly unsaturated acid (78\% linoleic acid) which reduces blood cholesterol level (3).

Currently, sufficient data on safflower production management is lacking. Therefore, the key objectives of the present study were to determine the effect of planting time and genotypes to optimize seed yield and quality parameters for the production of the safflower.

\section{Materials and Methods}

A field experiment was conducted at Agriculture Research Station, Annigeri (15 8 " N, 75 7" E and 624.8m amsl), University of Agricultural Sciences, Dharwad as part of All-India Coordinated Research Project on Safflower during rabi seasons of 2015-16 under rainfed condition.

The soil is clayey in texture (Vertisol) with $\mathrm{pH}$ of 7.95 , bulk density of $1.27 \mathrm{dS} / \mathrm{m}$ and available N:P:K of 224, 21 and $342 \mathrm{~kg}$ per ha. The experiment included two factors; three varieties and three sowing periods laid out in split-plot design with three replications. First sowing was done on $1^{\text {st }}$ October 2015, but second and third sowing were taken up at 15 days interval after first and second sowing, respectively $(7,8)$.

\section{Results and Discussion}

\section{0 seed weight $(g)$}

Among the date of sowing, significantly higher 100 seed weight $(4.56 \mathrm{~g})$ recorded is $1^{\text {st }}$ October, 2015 sowing as compared to other two date of sowing, with respect to genotypes, significantly higher 100 seed weight $(5.29 \mathrm{~g})$ recorded in $1^{\text {st }}$ October, 2015 sowing as compared to other two date of sowing (2). Interaction between DAS and genotypes did not any significant difference (Table 1).

\section{Seed yield (kg/ha)}

Among the date of sowings, however, the crop sown during first fortnight of October (115 Oct.) recorded significantly higher seed yield $(937 \mathrm{~kg} / \mathrm{ha})$ as compared with latter sowing dates. Among the safflower cultivars, significantly the highest seed yield was recorded with A-1 (1033 kg/ha) as compared with the yield of NARI-6 and NARI-57. The newly released genotypes (NARI-6 and NARI-57) did not perform as well as age old and locally very popular cultivar (A-1) under dryland ecosystem of northern Karnataka. Although interactions between planting date and genotypes were non-significant early sowing (1-15 of October) with A-1 variety recorded higher seed yield of $1127 \mathrm{~kg} / \mathrm{ha}$, than other combinations. Further, late sowing not only exposed the crop to warmer temperature, especially during second year all through the growing period until maturity but also exhausted residual soil moisture much faster for the crop to experience soil moisture, thus affected seed yield. Irrespective of initial stored soil moisture and rains during postrainy season, early sowing (1-1, Oct.) has 
been found to be optimum to realize higher yields and among the three varieties tested the good old A-1 variety seems to be more adapted to extremes of northern dry zone and performed much better than NARI-6 and NARI-57 $(11,12,15)$.

\section{Quality parameters}

\section{Oil content $(\%)$}

Among the genotypes NARI-6 recorded significantly higher oil content $(34.41 \%)$ as compared to $A_{1}$. But it was on par NARI-57. However, oil content did not show any significant differences with respect to date of sowing. Interaction between DAS and genotypes also did not significant difference $(6,14)$.

\section{Oil yield (kg/ha)}

Oil yield did not show any significant difference with respect to date of sowing, genotypes and interaction between date of sowing and genotypes (9).

Table.1 Influence of planting time and genotypes on seed yield and quality parameters

\begin{tabular}{|c|c|c|c|c|}
\hline Treatments & 100 seed wt & $\begin{array}{c}\text { Seed yield } \\
\text { (kg/ha) }\end{array}$ & $\begin{array}{l}\text { Oil content } \\
(\%)\end{array}$ & $\begin{array}{c}\text { Oil yield } \\
(\mathrm{kg} / \mathrm{ha})\end{array}$ \\
\hline \multicolumn{5}{|l|}{ Main plots: Genotypes } \\
\hline$D_{1}: 1-10-2015$ & 4.56 & 946 & 32.37 & 302 \\
\hline$D_{2}: 15-10-2015$ & 4.04 & 928 & 32.36 & 299 \\
\hline$D_{3}: 31-10-2015$ & 4.21 & 783 & 32.85 & 254 \\
\hline SEm \pm & 0.10 & 38 & 0.47 & 12 \\
\hline $\mathrm{CD}(\overline{\mathbf{P}}=\mathbf{0 . 0 5})$ & 0.34 & 131 & NS & NS \\
\hline \multicolumn{5}{|c|}{ Sub Plots: Date of sowing } \\
\hline $\mathbf{G}_{1}-\mathbf{A}_{1}$ & 5.29 & 1033 & 28.83 & 297 \\
\hline$G_{2}$-NARI-6 & 3.82 & 799 & 34.41 & 275 \\
\hline$G_{3}$-NARI-57 & 3.69 & 825 & 34.35 & 281 \\
\hline $\operatorname{SEm} \pm$ & 0.14 & 29 & 0.80 & 11 \\
\hline $\mathrm{CD}(\overline{\mathbf{P}}=\mathbf{0 . 0 5})$ & 0.41 & 87 & 2.38 & NS \\
\hline \multicolumn{5}{|l|}{ Interaction } \\
\hline$D_{1} G_{1}$ & 5.87 & 1127 & 27.81 & 313 \\
\hline $\mathbf{D}_{1} \mathbf{G}_{2}$ & 3.99 & 895 & 34.68 & 310 \\
\hline$D_{1} G_{3}$ & 3.81 & 818 & 34.62 & 282 \\
\hline $\mathbf{D}_{2} \mathbf{G}_{1}$ & 4.65 & 1019 & 29.65 & 302 \\
\hline $\mathbf{D}_{2} \mathbf{G}_{2}$ & 3.82 & 793 & 35.46 & 282 \\
\hline $\mathbf{D}_{2} \mathbf{G}_{3}$ & 3.65 & 972 & 31.98 & 313 \\
\hline $\mathbf{D}_{3} \mathbf{G}_{1}$ & 5.36 & 955 & 29.04 & 278 \\
\hline $\mathbf{D}_{3} \mathbf{G}_{2}$ & 3.65 & 710 & 33.09 & 235 \\
\hline $\mathbf{D}_{3} \mathbf{G}_{3}$ & 3.61 & 684 & 36.44 & 249 \\
\hline SEm \pm & 0.22 & 56 & 1.23 & 20 \\
\hline $\mathrm{CD}(\overline{\mathbf{P}}=\mathbf{0 . 0 5})$ & NS & NS & NS & NS \\
\hline
\end{tabular}


Table.2 Influence of planting time and genotypes on economics

\begin{tabular}{|c|c|c|c|}
\hline Treatments & $\begin{array}{l}\text { Gross return } \\
\text { (Rs/ha) }\end{array}$ & $\begin{array}{c}\text { Net return } \\
\text { (Rs/ha) }\end{array}$ & B:C ratio \\
\hline \multicolumn{4}{|l|}{ Main plots: Genotypes } \\
\hline$D_{1}: 1-10-2015$ & 28936 & 12436 & 1.75 \\
\hline$D_{2}: 15-10-2015$ & 22383 & 5883 & 1.36 \\
\hline$D_{3}: 31-10-2015$ & 23088 & 6588 & 1.40 \\
\hline \multicolumn{4}{|l|}{ SEm \pm} \\
\hline \multicolumn{4}{|l|}{$\mathrm{CD}(\overline{\mathbf{P}}=\mathbf{0 . 0 5})$} \\
\hline \multicolumn{4}{|l|}{ Sub Plots: Date of sowing } \\
\hline $\mathbf{G}_{1}-\mathbf{A}_{1}$ & 26502 & 10002 & 1.61 \\
\hline$G_{2}$-NARI-6 & 25983 & 9483 & 1.57 \\
\hline G3-NARI-57 & 21922 & 5422 & 1.33 \\
\hline \multicolumn{4}{|l|}{ SEm \pm} \\
\hline \multicolumn{4}{|l|}{$\mathrm{CD}(\overline{\mathbf{P}}=\mathbf{0 . 0 5})$} \\
\hline \multicolumn{4}{|l|}{ Interaction } \\
\hline$D_{1} G_{1}$ & 31543 & 15043 & 1.91 \\
\hline $\mathbf{D}_{1} \mathbf{G}_{2}$ & 25062 & 8562 & 1.52 \\
\hline$D_{1} G_{3}$ & 22901 & 6401 & 1.39 \\
\hline $\mathbf{D}_{2} \mathbf{G}_{1}$ & 28518 & 12018 & 1.73 \\
\hline $\mathbf{D}_{2} \mathbf{G}_{2}$ & 22210 & 5710 & 1.35 \\
\hline$D_{2} \mathbf{G}_{3}$ & 27222 & 10722 & 1.65 \\
\hline$D_{3} G_{1}$ & 26747 & 10247 & 1.62 \\
\hline $\mathbf{D}_{3} \mathbf{G}_{2}$ & 19876 & 3376 & 1.20 \\
\hline $\mathbf{D}_{\mathbf{3}} \mathbf{G}_{\mathbf{3}}$ & 19142 & 2642 & 1.16 \\
\hline SEm \pm & - & - & - \\
\hline $\mathrm{CD}(\overline{\mathbf{P}}=\mathbf{0 . 0 5})$ & & & \\
\hline
\end{tabular}

\section{Economics}

With respect to date of sowing, highest gross return (28936 Rs./ha), net return (12436 $\mathrm{Rs} . / \mathrm{ha})$ and $\mathrm{B}: \mathrm{C}$ ratio $(1.75)$ recorded in $1^{\text {st }}$ October, 2015 as compared to other two date of sowing (Table 2). Among the genotypes $\mathrm{A}_{1}$ genotype recorded highest gross return (26502 Rs./ha), net return (10002 Rs./ha) and $\mathrm{B}: \mathrm{C}$ ratio (1.61) as compared to other two genotypes. Interaction between date of sowing and genotypes recorded highest gross return (31543 Rs./ha), net return (15043 Rs./ha) and B:C ratio (1.91) as compared to other combinations.

\section{References}

1. Ali, E. A. and Mahmoud, A. M., (2012). Effect of combination between organic and mineral fertilization on productivity of some safflower genotypes. World J. Agril. Sci., 8 (2) :134-140.

2. Bahman, R., Ebadi, A., Akbar, V and Seyed, H. M. 2013. The effects of nitrogen fertilizer on nutrient uptake, physiological traits and yield components of safflower (Carthamus tinctorius L.). Intl. J. Agron. Plant. Prod. 4 (3) : 355-364.

3. Belgin, C.G., Bilal and K. Mustafa, 2007, Oil content and fatty acid composition 
of some safflower varieties sown in spring and winter. Inter. J. Nat. and Eng. Sci., 1 (3): 11-15.

4. Biradar, S. A., (2008), In-situ green manuring of intercropped legumes on the performance of maizechickpea/ safflower cropping system under rainfed condition. Ph. D. Thesis, Univ. Agric. Sci., Dharwad, Karnataka (India).

5. Dordas, C. A. and Sioulas, C., (2008), Safflower yield, chlorophyll content, photosynthesis, and water use efficiency response to nitrogen fertilization under rainfed condition. Indust. Crops Prod., $27: 75-85$.

6. Golzarfar, M., Shirani Rad, A. M. and Delkhosh, B., (2011).Nitrogen and phosphorus rates effect on yield and oil content of safflower in two growing season. Intl. J. Sci. Adv. Technol., 1 (7): 60-64.

7. Gomez, K. A. and Gomez, A. A. 1983. Statistical procedure for Agricultural Research. John Wiley and Sons, New Delhi, p. 680.

8. Jackson, M. L., 1967, Soil Chemical Analysis, Prentice Hall of India Pvt. Ltd., New Delhi, India.

9. Mohamed, S. J., Jellings, A. J. and Fuller, M. P., (2012).Effect of nitrogen on safflower physiology and productivity. African Crop Sci. J., 20 (4): 225-237. Rev., 2: 1106-1116.

10. Mundel, H. H., Morrison, R. J., Blachshaw, R. E and Roth, B. 2004. Safflower production on the Canadian prairies: Revisited in 2004. Agri. Can. Res. Station. Lethbridge /Alberta T1J4B1, 11, 19, 23.

11. Ozel, A., Demirbilek, T. and Gur, M. T., (2004). Copur effects of different sowing date and intrarow spacing on yield and some agronomic traits of safflower (Carthamus tinctorius L.) under Harran Plain's arid conditions. Turkish J. Agric. Forestry, 28 : 413419.

12. Vishwanath, H., Pujari, B. T., Prakash, S. S., Ramesh babu And Deshmanya, J. B. 2006. Growth attributes, dry matter production and its partitioning and nutrient uptake studies in spainless safflower (Cartamus tinctorious L.) var NARI-6 as influenced by nitrogen and sulphur levels. Karnataka. J. Agric. Sci. 19(4): 913-917.

13. Weiss, E. A., (2000), Safflower: Oilseed Crops, 93-129, Blackwell Sci. Ltd., Victoria, Australia, pp. 606.

14. Yogesh, T. C., (2013). Effect of In-situ green manuring of legumes, NP levels and organic manures on growth, yield and quality of safflower. Ph. D. Thesis, Univ. Agric. Sci., Dharwad, Karnataka (India).

15. Zareie S., Golkar, P. and Mohammadi, N. G., (2011). Effect of nitrogen and iron fertilizers on seed yield and yield components of safflower genotypes. African J. Agric. Res., 6 (16): 39243929.

\section{How to cite this article:}

Somanagouda, G., T. T. Bhandiwaddar and Manjula Maralappanavar. 2020. Effect of Planting Time and Genotypes on Seed Yield, Quality Parameters and Economics on Safflower. Int.J.Curr.Microbiol.App.Sci. 9(04): 812-816. doi: https://doi.org/10.20546/ijcmas.2020.904.097 